OPEN ACCESS

Edited by:

Guillaume Thierry,

Bangor University, United Kingdom

Reviewed by:

Wendy Sandler,

University of Haifa, Israel

Patricia Schneider-Zioga

California State University, Fullerton,

United States

*Correspondence: Shigeru Miyagawa

miyagawa@mit.edu

Specialty section: This article was submitted to

Language Sciences,

a section of the journal

Frontiers in Psychology

Received: 30 July 2017 Accepted: 24 January 2018 Published: 20 February 2018

Citation:

Miyagawa S, Lesure $C$ and Nóbrega VA (2018) Cross-Modality Information Transfer: A Hypothesis about the Relationship among Prehistoric Cave Paintings, Symbolic

Thinking, and the Emergence of Language. Front. Psychol. 9:115. doi: 10.3389/fpsyg.2018.00115

\section{Cross-Modality Information Transfer: A Hypothesis about the Relationship among Prehistoric Cave Paintings, Symbolic Thinking, and the Emergence of Language}

\author{
Shigeru Miyagawa ${ }^{1,2 *}$, Cora Lesure ${ }^{1}$ and Vitor A. Nóbrega ${ }^{3}$ \\ ${ }^{1}$ Department of Linguistics and Philosophy, Massachusetts Institute of Technology, Cambridge, MA, United States, ${ }^{2}$ Center \\ for Research and Development of Higher Education, The University of Tokyo, Tokyo, Japan, ${ }^{3}$ Department of Linguistics, \\ University of São Paulo, São Paulo, Brazil
}

Early modern humans developed mental capabilities that were immeasurably greater than those of non-human primates. We see this in the rapid innovation in tool making, the development of complex language, and the creation of sophisticated art forms, none of which we find in our closest relatives. While we can readily observe the results of this high-order cognitive capacity, it is difficult to see how it could have developed. We take up the topic of cave art and archeoacoustics, particularly the discovery that cave art is often closely connected to the acoustic properties of the cave chambers in which it is found. Apparently, early modern humans were able to detect the way sound reverberated in these chambers, and they painted artwork on surfaces that were acoustic "hot spots," i.e., suitable for generating echoes. We argue that cave art is a form of cross-modality information transfer, in which acoustic signals are transformed into symbolic visual representations. This form of information transfer across modalities is an instance of how the symbolic mind of early modern humans was taking shape into concrete, externalized language. We also suggest that the earliest rock art found in Africa may constitute one of the first fossilized proxies for the expression of full-fledged human linguistic behavior.

Keywords: symbolic thinking, language, cave art, archeoacoustics, Khoisan

\section{INTRODUCTION}

An extraordinary trait that humans have, one that separates us from all other living beings, is our "unique symbolic cognitive style" (Tattersall, 2017). As the philosopher Ernst Cassirer noted, humans are not the animal rationale but the animal symbolicum (Cassirer, 2006, p. 31). Although other animals are capable of challenging cognitive behavior - for instance, the crow's ability to make stick tools (Bluff et al., 2007), and the apparent symbolically mediated behavior of late Neanderthal populations (Jaubert et al., 2016) - the human capacity for symbolic thinking is immeasurably greater and qualitatively distinct, so much so that Charles Darwin himself commented, "the difference between the mind of the lowest man and that of the highest animal is immense" (Darwin, 1871, p. 100). Alfred Russel Wallace, a co-discoverer of evolution by natural selection, was particularly puzzled because he did not see tangible evolutionary advantages to 
the products of this unique capacity for symbolic thinking, such as music and the arts (Wallace, 1870). Assuming that early human symbolic behavior can be read from the archeological record, we explore the emergence of cave and rock art in human evolution and assess its relation to the development of human language.

\section{WHEN DID SYMBOLIC THINKING APPEAR?}

When did we acquire this cognitive capacity for symbolic thinking ? $^{1}$ The answer to this question must necessarily be based on indirect evidence, since we do not have access to facts about the variability and heritability of this trait (Lewontin, 1998). Suppose we equate high cognitive ability with brain size. The hominid brain has been growing for 2 million years, doubling in size twice during that period (Holloway et al., 2004), with modern humans at the end of the line showing the highest encephalization quotient (Finlay, 2009). However, Neanderthals had a brain that was larger in volume than humans (Holloway, 1981). Even after discounting for the disproportionate size of the area dedicated to visual perception (Pearce et al., 2013), their brain size was still comparable to that of modern humans. Yet they did not develop the kinds of behavior, such as agriculture and language, that we associate with high cognitive ability (Tattersall, 2008, 2010).

Is there something else in human evolutionary history that would indicate some drastic and qualitative change in behavior, signaling the emergence of symbolic thinking? Tattersall (2008, 2012, 2016a,b, 2017) makes an intriguing observation about the pace of technological innovation. The first stone-tool technology appeared 2.5 million years ago (Semaw et al., 1997), and it stayed basically the same for a million years before innovation was introduced in the form of the Acheulean handaxe. Another million years went by before a significant innovation took place, in the form of core preparation. In other words, innovation was rare and interspersed with long stretches during which hardly any change occurred. But toward the end of the Pleistocene, a profound shift occurred: technological innovations began to appear in rapid progression, and this marked a "relatively abrupt and qualitative change in mental information processing" (Tattersall, 2017, p. 5). This era of rapid change corresponds approximately to markers of symbolic thinking, such as the pieces of engraved ochres (Henshilwood et al., 2002) and the marine pierced shells (Henshilwood et al., 2004; d'Errico et al., 2005) found at Blombos Cave, which have been dated back to around 70,000-100,000 years ago. ${ }^{2}$ These constitute the

\footnotetext{
${ }^{1}$ We understand symbolic thinking as an internalized abstract mode of reasoning capable of combining isolated symbolic representations into an array of structured meaningful expressions. Although many aspects of human symbolic abilities ought to be traced back from different animal species to some common ancestor (Cheney and Seyfarth, 1990; Zuberbühler et al., 1999; Hauser, 2001; Spelke, 2003; Carruthers, 2006; Hurford, 2007, among others), none of these aspects depend on the combinatorial mental algorithm responsible for giving rise to the distinctively human symbolic mode of thinking (Deacon, 1997; Hauser et al., 2002; Spelke, 2003; Hauser, 2009; Searle, 2009).

${ }^{2}$ These marine shells were presumably pierced as part of a symbolic ornamentation system (Henshilwood et al., 2004). Body ornamentation may have different interpretations in different human societies, but all such artifacts are eminently
}

first archeological proxies signaling the fixation of the human language faculty (Huijbregts, 2017).

\section{BEGINNINGS OF SYMBOLIC THINKING}

An often-noted early piece of evidence for symbolic thinking is the two slabs of ochre from the Blombos Cave in South Africa. Ochre is an iron-rich mineral that served several roles, including body decoration, along with more utilitarian roles (Watts, 2009; Hansen, 2011). In Blombos Cave, more than 8,000 pieces of ochre-like material have been found (Rosso et al., 2017). Some, like those in Figure 1, have geometric engravings and incisions.

It has been suggested that these regular patterns are a proxy for symbolic thinking (Henshilwood et al., 2002; Tattersall, 2009). ${ }^{3}$ The idea is that the ochre engravings are an external, abstract representation of internal high-order cognitive processes. This is similar to spoken language, which is an external form of highly complex internal cognitive representations and computation. Although Neanderthals produced etchings (Rodríguez-Vidal et al., 2014) and geometric structures (Jaubert et al., 2016), they apparently did not possess the cognitive capabilities that modern humans do (Tattersall, 2008, 2010; Mendez et al., 2016; Sankararaman et al., 2016; Vernot et al., 2016). ${ }^{4}$ The mechanisms for this heightened cognition involve computational processes that may also occur in other animals but that in humans "are uniquely powerful in their range, capacity and flexibility" (Heyes, 2012). ${ }^{5}$

\section{LIFE IN THE CAVES}

The rapid innovation in tool making and the production of the Blombos Cave ochres and pierced shells suggest that modern humans by around 100,000 years ago were able to tap some cognitive resource that had not existed before. We will look at a well-known phenomenon that heretofore has been sparsely considered as exemplifying symbolic thinking. This is the phenomenon of cave and rock art, which is found on every major continent occupied by modern humans (Bahn and Fossati, 1995, 2003; Bahn et al., 2008, 2012). We wish to understand the nature of the expressions of symbolic thinking inherent in these artifacts as a way to begin to understand the evolutionary process

symbolic (Vanhaeren, 2005; Vanhaeren and d'Errico, 2006; Kuhn and Stiner, 2007) and an archeological proxy for the presence of a symbolically mediated behavior (d'Errico and Vanhaeren, 2009).

${ }^{3}$ See also d'Errico et al. (2001), Henshilwood and Dubreuil (2009), Mourre et al. (2010).

${ }^{4}$ It is also worth mentioning that although apes can understand referential symbols (Rumbaugh and Washburn, 2003; Tomasello et al., 2005) and develop cultural traditions (Whiten, 2005), they do not spontaneously create symbolic systems in the wild (Deacon, 1997; d'Errico and Vanhaeren, 2009).

${ }^{5}$ There are a number of approaches to the evolutionary development of the high cognitive capacity in humans. See, for example, Heyes and Frith (2014) for a summary of some of these approaches. Some postulate that human cognition developed gradually over a long period, starting as early as before the Pleistocene. While we do not doubt that the basic cognitive capacity existed in early hominids, we believe that the big "push" that led to the unique and pervasive symbolic thinking of modern humans developed much later in evolution. 


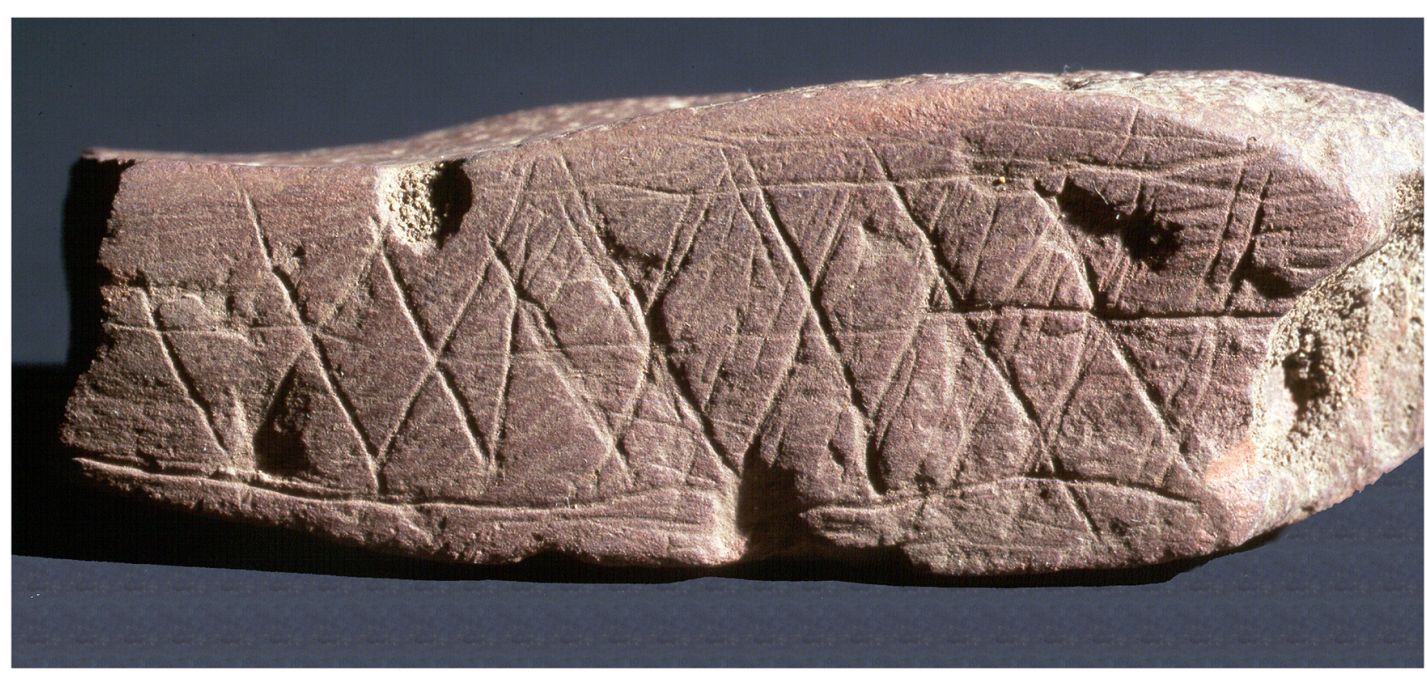

FIGURE 1 | Ochres from the Blombos Cave (Evolutionary Studies Institute University of the Witwatersrand)

that led to a fully developed symbolic species. We will show that our findings about these artifacts parallel aspects of human language.

We propose that the phenomenon of cave and rock art plausibly indicates how an internalized "system of thought" (Chomsky, 2011, 2013, 2015, 2016), which presumably evolved with the speciation of modern Homo sapiens around 200,000 years ago (Huijbregts, 2017), may have taken shape into concrete, externalized language. If this turns out to be true, the often-stated idea that "language does not fossilize" (e.g., Deacon, 1997; Fitch, 2010; Berwick and Chomsky, 2016) is not quite true: pieces of externalized language may turn out to be hidden among the art forms produced by our early modern human ancestors.

Some of the most striking artifacts from the life of early humans are the art forms found in caves throughout the world. Some of the most well-known are the Upper Paleolithic examples found in France and Spain. There are a number of puzzling features of this cave art that until recently escaped any rational explanation. These pictographs and petroglyphs are often found deep inside a cave, frequently in inaccessible locations. They tend to cluster narrowly in one location, ignoring nearby surfaces that appear to be just as suitable. And over ninety percent of the figures consist of hoofed animals (Gourhan-Leroi, 1967, 1982; Waller, 1993a, 2006).

A subfield of archeology, called archeoacoustics, has produced the idea that cave paintings are intimately related to the acoustic nature of the cave chambers (Reznikoff, 1987; Reznikoff and Dauvois, 1988). ${ }^{6}$ Hoffman (2014), for example, used a laptop

\footnotetext{
${ }^{6}$ The acoustic-visual correlation is widespread and it was found in the caves of France (viz., Le Portel, Niaux, Isturitz, Arcy-sur-Cure, Font-de-Gaume, Lascaux, Bernifal, among others; see Reznikoff and Dauvois, 1988; Waller, 1993b; Reznikoff, 1995, 2006; Dauvois, 1996, 1999, 2005), in the caves of Spain (viz., La Garma, El Castillo, La Pasiega, Las Chimeneas, Tito Bustillo; see Fazenda et al., 2017), and on two other continents (Waller, 1993a). Such diversity indicates that the correlation is not random.
}

and loudspeakers "to sweep a sine wave tone through all audio frequencies, recording the results to capture the acoustic fingerprint of each space." Such detailed studies of prehistoric sites support the idea that the subject matter and location of the pictures relate directly to the acoustics of the cave structure. Waller (2002) points out that the pictures often cluster in areas with enhanced acoustic properties. For instance, in the deep caves of Font-de-Gaume and Lascaux, pictures of hoofed animals such as bulls, bison, and deer appear in chambers in which the echoes, resonances, and reverberation created percussive sounds that resemble hoof beats ${ }^{7}$, as illustrated in Figure 2. In contrast to this, in chambers that are acoustically quiet, one finds pictures of felines (Waller, 1993a) or simple dots and handprints (Hoffman, 2014). ${ }^{8}$

Thus, acoustics offers a compelling explanation for the location of paintings in chambers deep inside caves, because these chambers have special acoustic properties; the clustering of paintings in certain areas of the cave wall, because they are acoustic "hot spots" (Blesser and Salter, 2009; Mattioli et al., 2017); and the predominance of hoofed animals as the subject matter of the paintings. Additionally, stalagmites and stalactites that ring like a musical instrument when struck have been found to be marked with paint (Hoffman, 2014).

\section{Cross-Modality Information Transfer}

Cave art, as analyzed by archeoacoustics, shows a flow of information from one modality to another: auditory

\footnotetext{
${ }^{7}$ Similar patterns were attested in other cave sites in France, such as Les Combarelles, Bernifal, Bara-Bahau, and Cougnac (see Waller, 1993b, for a detailed list).

${ }^{8}$ In a recent article, Fazenda et al. (2017) report on highly sophisticated acoustic tests together with statistical analysis in five caves in Northern Spain (viz., La Garma, Las Chimeneas, La Pasiega, El Catillo, and Tito Bustillo). They found that lines and dots are likely to occur in areas of low reverberation, while motifs of animals and other such depictions are likely to occur in areas with higher reverberation.
} 


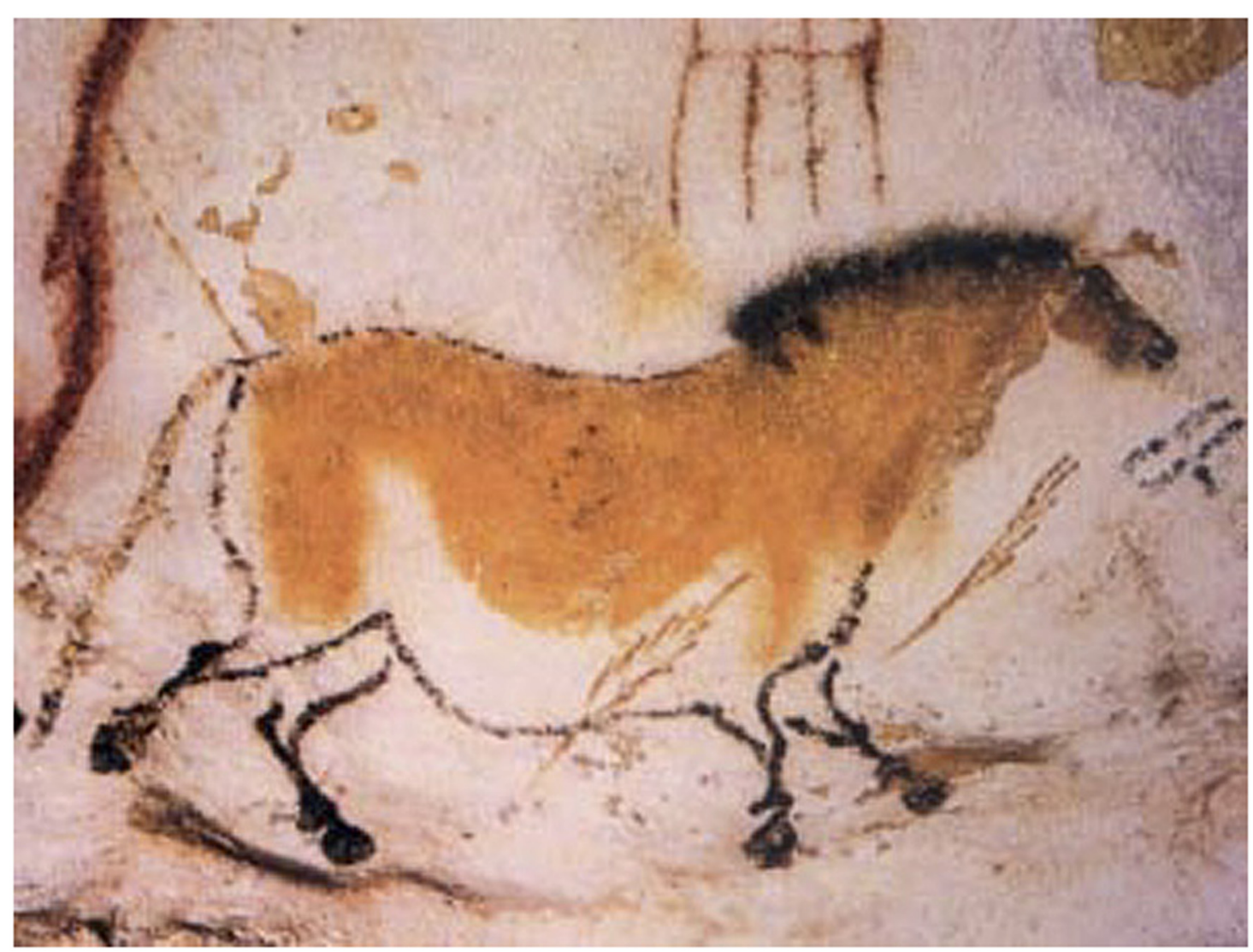

FIGURE 2 | Cave painting of a dun horse from Lascaux, circa 15,000 BC (Wikipedia) ${ }^{9}$.

to visual. The auditory modality is triggered by external input-thunder, rock tapping, music - and the auditory representation is mentally transformed into external, visual representation. This is a pure form of externalized symbolic thinking where information from one modality is transformed into representation in another modality. We speculate that this activity of information transfer across modalities allowed early humans to enhance their ability to convey symbolic thinking to their conspecifics, as well as their ability to process acoustic and visual input as symbolic (i.e., to associate acoustic and visual stimuli to a given mental representation).

Based on the archeological record we just reviewed, the externalization of the symbolic mode of thinking occurred some 100,000 years ago. It is possible that the cognitive underpinnings of symbolic thinking appeared at the time of the major genetic reorganization that resulted in the physical entity $H$. sapiens (Henshilwood and Dubreuil, 2009), and externalization occurred much later (Chomsky, 2010, 2013, 2017; Huijbregts, 2017). Or externalization may have begun closer to the formation of the new cognitive capacity. The activity of cross-modality information transfer (CMIT) constitutes one major effort to

\footnotetext{
${ }^{9}$ A reviewer observes that this image may have a hierarchical structure, which could possibly connect cave art to language.
}

connect the internalized system of thought to sensorimotor systems capable of representing and processing acoustic and visual stimuli. ${ }^{10}$

The idea that an activity like cave art, a form of CMIT, could have had such an enormous consequence for the development of modern humans is plausible on a couple of grounds. First, enormous effort was expended over 1000s of years to create this art (Waller, 2006). We hypothesize that the individuals who were able to transform symbolic thinking into sensory stimuli - likely privileged in the society- may have had a higher rate of reproductive success, thus spreading

\footnotetext{
${ }^{10}$ This perspective differs from other approaches to language evolution, such as Deacon's $(1997,2012)$, which proposes that the critical evolutionary threshold for the development of human language was the emergence of symbolic reference, allegedly absent in non-human animals. Many recent works on animal cognition suggest that the symbolic richness we find in the human species is attested in non-human animals (Cheney and Seyfarth, 1990; Zuberbühler et al., 1999; Hauser, 2001; Spelke, 2003; Carruthers, 2006; Hurford, 2007; Carey, 2009; among others). If this turns out to be correct, then it is plausible to claim, contrary to Deacon, that the emergence of a system of thought, rather than a semiotic innovation, was the key evolutionary ingredient that led to the emergence of human language. As Searle (2009) points out, it was syntax -i.e., the generative engine underlying such system of thought - that organized semantics, producing a new kind of logical representation in humans. As often speculated, the complexity of this system of thought did not emerge incrementally, rather it was likely full-fledged from its very beginning, even though it was not immediately externalized (Di Sciullo, 2014; Nóbrega and Miyagawa, 2015).
} 
the cognitive ability required for this practice through the population. ${ }^{11}$

Second, the population of $H$. sapiens early on was compact, around 9,000 when it emerged in Africa (Gronau et al., 2011). A cognitive modification even among a small group - viz., the cave artists - could have cut a large swath through the population quickly. It is no accident that 1000 s of cave-art sites have been discovered in 100s of countries (Blesser and Salter, 2009), indicating that a new cognitive capacity spread in the human population rapidly. In southern Africa alone, there are perhaps over a million cave-art images (Coulson and Campbell, 2001). ${ }^{12}$ But $H$. sapiens migrated out of Africa into the Eurasian continent some 60,000 years ago (Henn et al., 2012a). It is believed that by that time, the species already had its full modern capacity for symbolic thinking, including language (Henn et al., 2012b). Therefore, CMIT as exemplified by cave art must have started in Africa before the migration into the Eurasian continent. We turn to this topic below. ${ }^{13}$

\section{SAN ROCK ART}

The rock art of the San people constitutes evidence that rock art with CMIT properties may have existed in Africa prior to the migration of humans from the continent.

Anatomically modern humans appeared in central Africa 200,000 years ago. Gronau et al. (2011) carried out wholegenome sequencing on six individuals from different regions of the world: a European, a Yoruban, a Han Chinese, a Korean, a Bantu, and a San. The research shows that the San population was the first to split from other populations, and this occurred 108,000-157,000 years ago. They moved to southwest Africa, where they continue to reside to the present. Gronau et al.

\footnotetext{
${ }^{11}$ It is not evident who in society was creating these art forms, but there are certain characteristics about the placement of the art and its content that lend to indirect claims about artists and their purposes. For instance, the rock art of Kugpal, south India, is located in an area of very difficult access, which would preclude the engagement of large groups. According to Boivin (2004, p. 45), this implies that "the activities surrounding rock art may have been limited to a particular sector of the society," since not all members could equally participate in art production and consumption. The same sense of exclusivity emerges when we consider the shamanistic elements found in painted caves and rocks. Such features tend to support an association of these art forms with sacred rituals (see Lewis-Williams and Dowson, 1990; Lewis-Williams, 1991, 1997; Whitley, 1992, 1994, 1998; Clottes and Lewis-Williams, 1998; Ryan, 1999; Winkelman, 2002; Reznikoff, 2014), which consequently leads to the speculation that the artist could have been him/herself a shaman. Setting aside these speculations regarding authorship, it is reasonable to claim that the individuals who were endowed with the ability to translate symbolic thinking into sensory stimuli may have had reproductive advantages.

${ }^{12}$ It is worth mentioning that the best-known examples of cave art are found in Europe, dating back 40,000 years to the Upper Paleolithic period (Pike et al., 2012). ${ }^{13}$ It is important to highlight that the CMIT hypothesis does not rule out that other, parallel strategies for externalizing symbolic thinking may have been employed by early modern humans, such as manual gestures (Corballis, 2003, 2009, 2013), pantomimes and imitation (Arbib, 2002, 2009, 2012), and even sign language (Armstrong and Wilcox, 2007). Nevertheless, since we have to rely on indirect evidence to tentatively re-create the environment in which a symbolic mode of reasoning was externalized, the safest approach is to elaborate scenarios that can be empirically reconstructed. Such is the case with the discoveries in archeoacoustics: these can be recreated by means of, for instance, ambisonics technique, which can be applied "to identify the likely use of echolocation among societies for which no ethnographic information remains” (Mattioli et al., 2017, p. 12).
}

(2011) found that the Eurasian population diverged from the rest $38,000-64,000$ years ago, which marks the time that $H$. sapiens began to migrate out of Africa. ${ }^{14}$

Along with the genetic evidence for the San's early divergence from other human populations, there is also linguistic evidence. The San's languages belong to the Khoisan family. All biologically Khoisan groups speak a language with phonemic clicks (Güldemann and Stoneking, 2008), which are consonants with a distinctive popping sound. Khoisan can be seen as one of the only language families in the world with clicks (Huijbregts, 2017). The only other language family is Bantu, but only in areas of contact and intermarriage with Khoisan populations, indicating the borrowing of consonantal clicks into Bantu languages (Herbert, 2002; Maddieson, 2003; Sands abd Güldemann, 2009). ${ }^{15}$ As Huijbregts notes, this suggests that the San, once they split off from the rest of the human population, stayed relatively isolated, something also supported by the genetic research (Gronau et al., 2011). This means that anything we find in the population may very well have been there to begin with, possibly even before they split from other human populations.

The San produced rock art that has been dated as far back as 70,000 years ago (Thackeray, 2005). The rocks were decorated because it was believed that a spirit world existed beneath the surface (Lewis-Williams and Dowson, 1990). We find this type of rock art in other regions of the world as well, typically those with an animistic tradition (Bahn and Fossati, 1995, 2003). The idea of a spirit world behind the surface of the rock could come from the acoustic property of echo: an acoustic signal is detected despite the absence of a direct source for it at the point of the sound.

There are two important points about San rock art and its relationship to symbolic thinking. First, the fact that some of the rock art predates the migration out of Africa gives credence to the hypothesis that CMIT is an example of the expression of symbolic thinking and even a factor enhancing this capacity's spread throughout the human population. The second point relates to the apparent relative isolation of the San population from others in Africa and beyond, as indicated by the unique existence of clicks and by the genetics of the San population. The point Huijbregts (2017) makes is that the seeds of human language must have been there prior to the first genetic split, $\sim 125,000$ years ago. This is because other populations developed a language as well. So, some cognitive property that preceded the development of language existed prior to the first human lineage

\footnotetext{
${ }^{14}$ In a separate study, Veeramah et al. (2012) resequenced samples from four populations in Africa - San, Eastern Pygmies, Western Pygmies, and nonPygmy Niger-Kordofanian speakers- at 40 non-genic $(\sim 2 \mathrm{~kb})$ regions and came to essentially the same conclusion, that the San population diverged first, approximately 110,000 years ago.

${ }^{15} \mathrm{~A}$ piece of evidence for the borrowing of consonantal clicks into Bantu languages is the absence of clicks in Bantu languages outside the area where Khoisan languages are found (Pakendorf et al., 2017). Furthermore, genetic analyses of populations indicate that there was a prehistoric contact between Khoisan and Bantu-speaking populations. For instance, Barbieri et al. (2013) undertook an extensive genetic study of the Bantu population in order to elucidate the nature of the borrowing. Their analysis favors "admixture in the maternal line between some of the Bantu groups from Zambia and Khoisan-speaking populations," suggesting that the borrowing took place through "incorporation of Khoisan women" into the Bantu population; a conclusion endorsed by Pakendorf et al. (2017).
} 
split. If we assume that this cognitive property included symbolic thinking, the cognitive underpinnings underlying CMIT had taken root earlier than the split of the San population from the rest. $^{16}$

\section{CAVE AND ROCK ART AND HUMAN LANGUAGE}

Cave and rock art in general and language have a number of striking similarities:

- occur on every major continent

- possibly appeared about the same time, predating the migration out of Africa

- spread from Africa to all other parts of the world roughly at the same time

- are used for communication

- express actions, states, objects, and modification

- externalize internal mental states.

The first three points relate to the observation that artistic artifacts, either deep in caves or closer to the surface, occur on every continent occupied by modern humans (Bahn and Fossati, 1995, 2003), and the oldest occur in Africa (Henshilwood et al., 2002). The fourth point has to do with the function of art and of language: both are used for communication. ${ }^{17}$ The fifth point has to do with the content of artworks and of language: both may indicate actions (i.e., predicates), objects (i.e., nouns), and modification (i.e., adjectives).$^{18}$ The final point, that art and language are external symbolic forms of internal mental states, is an obvious one, and it also may connect the two to genetic studies. The FOXP2 gene is implicated for speech in humans and for other externalized communication forms in mice (Groszer et al., 2008; Castellucci et al., 2016; Chabout et al., 2016) and songbirds (Haesler et al., 2007), but only modern humans have art and language. Is there a genetic basis for

\footnotetext{
${ }^{16}$ A reviewer brought to our attention that the strong identifications between the San people and the eland, a type of antelope, may also express a mental representation in CMIT terms. According to Opoku (2006, p. 356), 77\% of the San rock arts involve antelopes. The importance of the antelope -more specifically, the eland - in San mythology can be noticed in their ritual behaviors, whereby the young San boys and girls virtually identify themselves with elands. As the reviewer points out "the visual stimuli of the eland is transformed into the kinetic gestures of the ritual" by the community, which may indicate that the artist who created the paintings "need not be the only source of the innovation in externalized expression although clearly he/she is the only one who left evidence of his/her cognitive ability."

${ }^{17}$ The communicative function of art can be inferred from the finding that cave paintings may have played a role in Paleolithic man's religious rituals (Reznikoff, 2014).

${ }^{18}$ We can even surmise that lexical categories such as verb, noun, and adjective may have been expressed in many of these artistic representations.
}

\section{REFERENCES}

Arbib, M. A. (2002). "The mirror system, imitation, and the evolution of language," in Imitation in Animals and Artifacts: Complex Adaptive Systems, eds K. Dautenhahn, C. L. Nehaniv (Cambridge, MA: The MIT Press), 229-280. this? FOXP2 underwent change in modern humans (VarghaKhadem et al., 1995; Lai et al., 2001) that affected a binding site for the transcription factor POU3F2 (Maricic et al., 2013; Huijbregts, 2017). The POU3F2 variant only occurs in modern humans, being absent from Neanderthals and Denisovans. As Huijbregts (2017) notes, this change could be seen as leading to the acquisition of full speech. Given the similarity with art, we can speculate with Huijbregts that a similar genetic change may have given rise to the multi-modal art that occurred all over the world alongside language.

\section{CONCLUDING REMARKS}

The symbolic thinking that developed in humans led to rapid technological innovation, sophisticated visual arts, and language. This newly formed cognitive capacity may have had another, unexpected result. After continuously growing in size over the span of the Pleistocene, our brain has contracted in size by $13 \%$ in the past 20,000 years or so (Hawks, 2011 and references therein). One possible explanation is that the symbolic thinking that developed in modern humans led to a fundamentally different way to compute data, one that extracts only the essence required for abstract representation instead of computing the entire set of incoming raw data (Tattersall, 2017). Our brain membrane is metabolically expensive, so the newly formed algorithm that requires less data led to shedding of the unneeded membrane, resulting in brain diminution in recent evolutionary time. Our proposal is that the symbolic thinking pervasive in humans that led to brain diminution is exemplified, and was even enhanced, by the CMIT that we see in the cave and rock art of Africa and elsewhere in the world and by the development of language. Thus, contrary to Wallace, the development of the arts gave the modern humans a powerful evolutionary advantage.

\section{AUTHOR CONTRIBUTIONS}

All authors listed have made a substantial, direct and intellectual contribution to the work, and approved it for publication.

\section{ACKNOWLEDGMENTS}

We are grateful to the two reviewers for extensive comments and suggestions on earlier versions of this paper. We also extend our appreciation to the editor, Guillaume Thierry, for carefully guiding the review process. VN's portion of this article was supported in part by the National Council of Technological and Scientific Development - CNPq (Grant No. 160605/2014-8).

Arbib, M. A. (2009). Evolving the language ready brain and the social mechanisms that support language. J. Commun. Disord. 42, 263-271. doi: 10.1016/j.jcomdis. 2009.03.009

Arbib, M. A. (2012). How the Brain Got Language: The Mirror System Hypothesis. Oxford: Oxford University Press. doi: 10.1093/acprof:osobl/9780199896684. 001.0001 
Armstrong, D. F., and Wilcox, S. (2007). The Gestural Origin of Language. Oxford: Oxford University Press. doi: 10.1093/acprof:oso/9780195163483.001.0001

Bahn, P., and Fossati, A. (1995). Rock Art Studies: News of the World I. Oxford: Oxbow Books.

Bahn, P., and Fossati, A. (2003). Rock Art Studies: News of the World II. Oxford: Oxbow Books.

Bahn, P., Franklin, N., and Fossati, A. (2012). Rock Art Studies: News of the World IV. Oxford: Oxbow Books.

Bahn, P., Franklin, N., and Strecker, M. (2008). Rock Art Studies: News of the World III. Oxford: Oxbow Books.

Barbieri, C., Butthof, A., Bostoen, K., and Pakendorf, B. (2013). Genetic perspectives on the origin of clicks in Bantu languages from southwestern Zambia. Eur. J. Hum. Genet. 21, 430-436. doi: 10.1038/ejhg. 2012.192

Berwick, R., and Chomsky, N. (2016). Why Only Us? Language and Evolution. Cambridge, MA: MIT Press.

Blesser, B., and Salter, L.-R. (2009). Spaces Speak, Are you Listening? Cambridge, MA: MIT Press.

Bluff, L. A., Weir, A. S., Rutz, C., Wimpenny, J. H., and Kacelnik, A. (2007). Tool-related cognition in New Caledonian crows. Comp. Cogn. Behav. Rev. 2, $1-25$.

Boivin, N. (2004). Rock art and rock music: Petroglyphs of south Indian Neolithic. Antiquity 78, 38-53. doi: 10.1017/S0003598X00092917

Carey, S. (2009). The Origin of Concepts. Oxford: Oxford University Press. doi: 10.1093/acprof:oso/9780195367638.001.0001

Carruthers, P. (2006). The Architecture of the Mind. Oxford: Oxford University Press. doi: 10.1093/acprof:oso/9780199207077.001.0001

Cassirer, E. (2006). "An essay on man," in Gesammelten Werke Bd 23, ed. B. Recki (Hamburg: Meiner).

Castellucci, G. A., McGinley, M. J., and McCornick, D. A. (2016). Knockout of Foxp2 disrupts vocal development in mice. Sci. Rep. 6:23305. doi: 10.1038/ srep23305

Chabout, J., Sarkar, A., Patel, S. R., Radden, T., Dunson, D. B., Fisher, S. E., et al. (2016). A Foxp2 mutation implicated in human speech deficits alters sequencing of ultrasonic vocalizations in adult male mice. Front. Behav. Neurosci. 10:197. doi: 10.3389/fnbeh.2016.00197

Cheney, D. L., and Seyfarth, R. M. (1990). How Monkeys see the World. Chicago, IL: University of Chicago Press.

Chomsky, N. (2010). "Some simple evo-devo theories about language: How might they be true for language?," in The Evolution of Human Language: Biolinguistic Perspectives, eds R. K. Larson, V. Déprez, and H. Yamakido (Cambridge: Cambridge University Press), 45-62.

Chomsky, N. (2011). Language and other cognitive systems. What is special about language? Lang. Learn. Dev. 7, 263-278. doi: 10.1080/15475441.2011.58 4041

Chomsky, N. (2013). Problems of projection. Lingua 130, 33-49. doi: 10.1016/j. lingua.2012.12.003

Chomsky, N. (2015). The Minimalist Program: 20th Anniversary Edition. Cambridge, MA: MIT Press.

Chomsky, N. (2016). What Kind of Creatures are we? New York, NY: Columbia University Press.

Chomsky, N. (2017). Language architecture and its import for evolution. Neurosci. Biobehav. Rev. 81, 295-300. doi: 10.1016/j.neubiorev.2017. 01.053

Clottes, J., and Lewis-Williams, D. (1998). The Shamans of Prehistory: Trance and Magic in the Painted Caves. New York, NY: Harry Abrams.

Corballis, M. C. (2003). "From hand to mouth: the gestural origins of language," in Language Evolution, eds M. H. Christiansen and S. Kirby (Oxford: Oxford University Press), 201-218.

Corballis, M. C. (2009). The gestural origins of language. WIREs Cogn. Sci. 1, 2-7. doi: $10.1002 /$ wcs. 2

Corballis, M. C. (2013). "Gestural theory of the origins of language," in New Perspectives on the Origins of Language, eds C. Lefebvre, B. Comrie, and H. Cohen (Amsterdam: John Benjamins Publishing), 171-184.

Coulson, D., and Campbell, A. (2001). African Rock art - Paintings and Engravings on Stone. New York, NY: Harry N. Abrams.

Darwin, C. (1871). The Descent of Man, and Selection in Relation to Sex. London: John Murray.
Dauvois, M. (1996). Evidence of sound-making and the acoustic character of the decorated caves of the Western Paleolithic World. Int. Newsl. Rock Art 13, 23-25.

Dauvois, M. (1999). "Mesures acoustiques et témoins sonores osseux paléolithiques," in Préhistoire d'os, Recuel d'études sur lindustrie Osseuse Préhistorique, ed. H. Camps-Fabrer (Provence: Publication de l'Université de Provence), 165-189.

Dauvois, M. (2005). Homo musicus palaeolithicus et palaeoacustica. Munibe 57, 225-241.

Deacon, T. (1997). The Symbolic Species: The Coevolution of Language and the Brain. New York, NY: W. W. Norton \& Co.

Deacon, T. W. (2012). "Beyond the symbolic species," in The Symbolic species Evolved - Biosemiotics 6, eds T. Schilhab, F. Stjerfelt, and T. W. Deacon (New York, NY: Springer), 9-38. doi: 10.1007/978-94-007-2336-8_2

d'Errico, F., Henshilwood, C., Vanhaeren, M., and van Niekerk, K. (2005). Nassarius kraussianus shell beads from blombos cave: evidence for symbolic behaviour in the middle stone age. J. Hum. Evol. 48, 3-24. doi: 10.1016/j.jhevol. 2004.09.002

d'Errico, F., Henshilwood, C. S., and Nilssen, P. (2001). An engraved bone fragment from ca. $75 \mathrm{kyr}$ middle stone age levels at blombos Cave, South Africa: implications for the origin of symbolism and language. Antiquity 75, 309-318. doi: 10.1017/S0003598X00060968

d'Errico, F., and Vanhaeren, M. (2009). "Earliest personal ornaments and their significance for the origin of language debate," in The Cradle of Language, eds R. Botha and C. Knight (Oxford: Oxford University Press), 16-40.

Di Sciullo, A. M. (2014). "Minimalism and I-Morphology," in Minimalism and Beyond: Radicalizing the Interfaces, eds P. Kosta, L. Schurcks, and T. RadevBork (Amsterdam: John Benjamins), 267-286.

Fazenda, B., Scarre, C., Till, R., Pasalodos, R. J., Guerra, M. R., Tejedor, C., et al. (2017). Cave acoustics in prehistory: exploring the association of Palaeolithic visual motifs and acoustic response. J. Acoust. Soc. Am. 142:1332. doi: 10.1121/ 1.4998721

Finlay, B. L. (2009). "Brain evolution: developmental constraints and relative developmental growth," in Encyclopedia of Neuroscience, Vol. 2, ed L. R. Squire (Oxford: Oxford University Press), 337-345.

Fitch, W. T. (2010). The Evolution of Language. Cambridge: Cambridge University Press. doi: 10.1017/CBO9780511817779

Gourhan-Leroi, A. (1967). Treasures of Prehistoric Art. New York, NY: Harry N. Abrams.

Gourhan-Leroi, A. (1982). The Dawn of European art: An Introduction to Palaeolithic Cave Painting. Cambridge: Cambridge University Press.

Gronau, I., Hubisz, M. J., Gulko, B., Danko, C. G., and Siepel, A. (2011). Bayesian inference of ancient human demography from individual genome sequences. Nat. Genet. 43, 1031-1034 doi: 10.1038/ng.937

Groszer, M., Keays, D. A., Deacon, R. M., de Bono, J. P., Prasad-Mulcare, S., Gaub, S., et al. (2008). Impaired synaptic plasticity and motor learning in mice with a point mutation implicated in human speech deficits. Curr. Biol. 18, 354-362 doi: 10.1016/j.cub.2008.01.060

Güldemann, T., and Stoneking, M. (2008). A historical appraisal of clicks: a linguistic and genetic population perspective. Annu. Rev. Anthropol. 37, 93-109. doi: 10.1146/annurev.anthro.37.081407.085109

Haesler, S., Rochefort, C., Georgi, B., Licznersk, P., Osten, P., and Scharff, C. (2007). Incomplete and inaccurate vocal imitation after knockdown of FoxP2 in songbird basal ganglia nucleus Area X. PLOS Biol. 5:e321. doi: 10.1371/journal. pbio. 0050321

Hansen, I. A. (2011). The Role of Ochre in the Middle Stone Age. MA thesis, University of Oslo, Oslo.

Hauser, M. D. (2001). Wild Minds: What Animals Really Think. New York, NY: Owl Books.

Hauser, M. D. (2009). The possibility of impossible cultures. Nature 460, 190-196. doi: $10.1038 / 460190$ a

Hauser, M. D., Chomsky, N., and Fitch, W. T. (2002). The faculty of language: what is it, who has it, and how did it evolve? Science 298, 1569-1579.

Hawks, J. (2011). No brain expansion. Australopithecus boisei. Am. J. Phys. Anthropol. 146, 155-160. doi: 10.1002/ajpa.21420

Henn, B. M., Botigué, L. R., Gravel, S., Wang, W., Brisbin, A., Byrnes, JK., et al. (2012a). Genomic ancestry of North Africans supports back-to-Africa migrations. PLOS Genet. 8:e1002397. doi: 10.1371/journal.pgen.1002397 
Henn, B. M., Cavalli-Sforza, L. L., and Feldman, M. W. (2012b). The great human expansion. Proc. Natl. Acad. Sci. U.S.A. 109, 17758-17764. doi: 10.1073/pnas. 1212380109

Henshilwood, C. S., d'Errico, F., Yates, R., Jacobs, Z., Tri-bolo, C., Duller, G. A. T., et al. (2002). Emergence of modern human behaviour: middle stone age engravings from South Africa. Science 295, 1278-1280. doi: 10.1126/science. 1067575

Henshilwood, C. S., and Dubreuil, B. (2009). "Reading the artifacts: gleaning language skills from the Middle Stone Age in southern Africa," in The Cradle of Language, eds R. Botha and C. Knight (Oxford: Oxford University Press), 41-61.

Henshilwood, C. S., Vanhaeren, M., van Niekerk, K., and Jacobs, Z. (2004). Middle stone age shell beads from South Africa. Science 304:404. doi: 10.1126/science. 1095905

Herbert, R. K. (2002). "The sociohistory of clicks in southern Bantu," in Language in South Africa, ed. R. Mesthrie (Cambridge: Cambridge University Press), 297-315.

Heyes, C. (2012). New thinking: the evolution of human cognition. Philos. Trans. R. Soc. Lond. B Biol. Sci. 367, 2091-2096. doi: 10.1098/rstb.2012.0111

Heyes, C. M., and Frith, C. D. (2014). The cultural evolution of mind reading. Science 344:1243091. doi: 10.1126/science.1243091

Hoffman, J. (2014). Q\&A: Acoustic archaeologist. Nature 506:158. doi: 10.1038/ $506158 \mathrm{a}$

Holloway, R. L. (1981). Volumetric and asymmetry determinations on recent hominid endocasts: Spy I and II, Djebel Ihroud I, and the Sale Homo erectus specimens, with some notes on Neanderthal brain size. Am. J. Phys. Anthropol. 55, 385-393. doi: 10.1002/ajpa.1330550312

Holloway, R. L., Broadfield, D. C., and Yuan, M. S. (2004). "Brain endocasts: the paleoneurological evidence," in The Human Fossil Record, Vol. 3, eds J. H. Schwartz and I. Tattersall (New York, NY: Wiley-Liss). doi: 10.1002/0471663573

Huijbregts, M. A. C. R. (2017). Phonemic clicks and the mapping asymmetry: how language emerged and speech developed. Neurosci. Biobehav. Rev. 81, 279-294. doi: 10.1016/j.neubiorev.2017.01.041

Hurford, J. R. (2007). The Origins of Meaning. Oxford: Oxford University Press.

Jaubert, J., Verheyden, S., Genty, D., Soulier, M., Cheng, H., Blamart, D., et al. (2016). Early neanderthal constructions deep in bruniquel cave in southwestern France. Nature 534, 111-114. doi: 10.1038/nature18291

Kuhn, S. L., and Stiner, M. C. (2007). Paleolithic ornaments: implications for cognition, demography and identity. Diogenes 214, 40-48. doi: 10.1177/ 0392192107076870

Lai, E. C., Deblandre, G. A., Kintner, C., and Rubin, G. M. (2001). Drosophila neuralized is a ubiquitin ligase that promotes the internalization and degradation of delta. Dev. Cell 1, 783-794. doi: 10.1016/S1534-5807(01)00092-2

Lewis-Williams, D. J. (1991). Wrestling with analogy: a methodological dilemma in Upper Paleolithic parietal art. Proc. Prehistor. Soc. 57, 149-162. doi: 10.1017/ S0079497X00004941

Lewis-Williams, D. J. (1997) "Harnessing the brain: visions and shamanism in Upper Paleolithic Western Europe," in Beyond Art: Pleistocene Image and Symbol, Vol. 23, eds M. Conkey, O. Soffer, D. Stratmann, and N. Jablonski (Berkeley, CA: Memoirs of the California Academy of Sciences), 321-342.

Lewis-Williams, D. J., and Dowson, T. A. (1990). Through the veil: san rock paintings and the rock face. S. Afr. Archaeol. Bull. 45, 5-16. doi: 10.2307/ 3887913

Lewontin, R. C. (1998) "The evolution of cognition: questions we will never answer," in An Invitation to Cognitive Science: Methods, Models, and Conceptual Issues, Vol. 4, eds D. Scarborough and S. Sternberg (Cambridge, MA: MIT Press), 107-132.

Maddieson, I. (2003). "The sounds of the Bantu languages," in The Bantu Languages, eds D. Nurse and G. Philippson (New York, NY: Routledge), 15-41.

Maricic, T., Günther, V., Georgiev, O., Gehre, S., Curlin, M., Schreiweis, C., et al. (2013). A recent evolutionary change affects a regulatory element in the human FOXP2 gene. Mol. Biol. Evol. 30, 844-852. doi: 10.1093/molbev/mss271

Mattioli, T., Farina, A., Armelloni, E., and Díaz-Andreu, M. (2017). Echoing landscapes: echolocation and the placement of rock art in the Central Mediterranean. J. Archeol. Sci. 83, 12-25. doi: 10.1016/j.jas.2017.04.008

Mendez, F. L., Poznik, G. D., Castellano, S., and Bustamante, C. D. (2016). The divergence of Neandertal and modern human Y chromosomes. AJHG 98, 728-734. doi: 10.1016/j.ajhg.2016.02.023
Mourre, V., Villa, P., and Henshilwood, C. S. (2010). Early use of pressure flaking on Lithic artifacts at Blombos Cave, South Africa. Science 330, 659-662. doi: $10.1126 /$ science. 1195550

Nóbrega, V. A., and Miyagawa, S. (2015). The precedence of syntax in the rapid emergence of human language in evolution as defined by the integration hypothesis. Front. Psychol. 6:271. doi: 10.3389/fpsyg.2015.00271

Opoku, K. (2006). "Animals in African mythology," in A Communion of Subjects: Animals in Religion, Science, and Ethics, eds P. Waldau and K. Patton (New York, NY: Columbia University Press), 351-359.

Pakendorf, B., Gunnink, H., Sands, B., and Bostoen, K. (2017). Prehistoric bantukhoisan language contact: a cross-disciplinary approach. Lang. Dyn. Change 7 , 1-46. doi: 10.1163/22105832-00701002

Pearce, E., Stringer, C., and Dunbar, R. I. M. (2013). New insights into differences in brain organization between Neanderthals and anatomically modern humans. Proc. R. Soc. Lond. B Biol. Sci. 280, 1-7. doi: 10.1098/rspb.2013.0168

Pike, A. W. G., Hoffmann, D. L., García-Diez, M., Pettitt, P. B., Alcolea, J., de Balbín, R., et al. (2012). U-series dating of Paleolithic art in 11 caves in Spain. Science 336, 1409-1413. doi: 10.1126/science. 1219957

Reznikoff, I. (1987). Sur la dimension sonore des grottes à peintures du paléolithique. C R Acad. Sci. 304, 153-156.

Reznikoff, I. (1995). "On the sound dimension of prehistoric painted caves and rocks," in Musical Signification: Essays on the Semiotic Theory and Analysis of Music, ed. E. Taratsi (New York, NY: Mouton de Gruyter), 541-557.

Reznikoff, I. (2006). "The evidence of the use of sound resonance from Palaeolithic to Medieval times," in Archaeoacoustics, eds C. Scarre and G. Lawson (Cambridge: McDonald Institute Monographs), 77-84.

Reznikoff, I. (2014). On the sound related to painted caves and rocks. Monogr. Archaeol. Soc. Finland 2, 101-109.

Reznikoff, I., and Dauvois, M. (1988). La dimension sonore des grottes ornées. Bull. Soc. Préhistor. Fr. 85, 238-246. doi: 10.3406/bspf.1988.9349

Rodríguez-Vidal, J., d'Errico, F., Pacheco, F. G., Blasco, R., Rosell, J., Jennings, R. P., et al. (2014). A rock engraving made by Neanderthals in Gibraltar. Proc. Natl. Acad. Sci. U.S.A. 111, 13301-13306. doi: 10.1073/pnas.141152 9111

Rosso, D. E., d'Errico, F., and Queffelec, A. (2017). Patterns of change and continuity in ochre use during the late Middle Stone Age of the Horn of Africa: The Porc-Epic Cave record. PLOS ONE 12:e0177298 doi: 10.1371/journal.pone. 0177298

Rumbaugh, D. M., and Washburn, D. A. (2003). Intelligence of Apes and Other Rational Beings. New Haven, CT: Yale University Press. doi: 10.12987/yale/ 9780300099836.001.0001

Ryan, R. (1999). The Strong Eye of Shamanism: A Journey into the Caves of Consciousness. Rochester, NY: Inner Traditions.

Sands, B., abd Güldemann, T. (2009). "What click languages can and can't tell us about language origins," in The Cradle of Language, eds R. P. Botha and C. Knight (Oxford: Oxford University Press), 204-218.

Sankararaman, S., Mallick, S., Patterson, N., and Reich, D. (2016). The combined landscape of Denisovan and Neanderthal ancestry in present-day humans. Curr. Biol. 26, 1241-1247. doi: 10.1016/j.cub.2016.03.037

Searle, J. R. (2009). What is language? Some preliminary remarks. Ethics Polit. 1, 173-202.

Semaw, S., Renne, P., Harris, J. W. K., Feibel, C. S., Bernor, R. L., Fesseha, N., et al. (1997). 2.5-million-year- old stone tools from Gona, Ethiopia. Nature 385, 333-336. doi: 10.1038/385333a0

Spelke, E. (2003). "What makes us smart? Core knowledge and natural language," in Language and Mind: Advances in the Study of Language and Thought, eds D. Gentner and S. Goldin-Meadow (Cambridge, MA: MIT Press), 277-311.

Tattersall, I. (2008). An evolutionary framework for the acquisition of symbolic cognition by Homo sapiens. Comp. Cogn. Behav. Rev. 3, 99-114. doi: 10.3819/ ccbr.2008.30006

Tattersall, I. (2009). "Language and the origin of symbolic thought," in Cognitive Archaeology and Human Evolution, eds S. A. de Beaune, F. L. Coolidge, and T. Wynn (Cambridge: Cambridge University Press), 109-116.

Tattersall, I. (2010). Human evolution and cognition. Theory Biosci. 129, 193-201. doi: 10.1007/s12064-010-0093-9

Tattersall, I. (2012). Masters of the Planet: The Search for Our Human Origins. New York, NY: Palgrave Macmillan. 
Tattersall, I. (2016a). A tentative framework for the acquisition of language and modern human cognition. J. Anthropol. Sci. 94, 157-166. doi: 10.4436/jass. 94030

Tattersall, I. (2016b). Language origins: an evolutionary framework. Topoi 1-8. doi: 10.1007/s11245-016-9368-1

Tattersall, I. (2017). “Why was human evolution so rapid?," in Human Palentology and Prehistory, eds A. Marom and E. Hovers (New York, NY: Springer), 1-9.

Thackeray, F. (2005). Eland, hunters and concepts of 'sympathetic control' expressed in southern African rock art. Camb. Archaecol. J. 15, 27-34. doi: 10.1017/S0959774305000028

Tomasello, M., Carpenter, M., Call, J., Behne, T., and Moll, H. (2005). Understanding and sharing intentions: the origins of cultural cognition. Behav. Brain Sci. 28, 675-735. doi: 10.1017/S0140525X05000129

Vanhaeren, M. (2005). “The evolutionary significance of beadmaking and use," in From Tools to Symbols, eds F. d'Errico and L. Backwell (Johannesburg: Wits University Press), 525-535.

Vanhaeren, M., and d'Errico, F. (2006). Aurignacian ethnolinguistic-geography of Europe revealed by personal ornaments. J. Archaeol. Sci. 33, 1105-1128. doi: 10.1016/j.jas.2005.11.017

Vargha-Khadem, F., Watkins, K., Alcock, K., and Flethcer, P. Passigham, R. (1995). Praxic and nonverbal cognitive deficits in a large family with a genetically transmitted speech and language disorder. Proc. Natl. Acad. Sci. U.S.A. 92, 930-933. doi: 10.1073/pnas.92.3.930

Veeramah, K. R., Wegmann, D., Woerner, A., Mendez, F. L., Watkins, J. C., DestroBisol, G., et al. (2012). An early divergence of KhoeSan ancestors from those of other modern humans is supported by an ABC-based analysis of autosomal resequencing data. Mol. Biol. Evol. 29, 617-630. doi: 10.1093/molbev/msr212

Vernot, B., Tucci, S., Kelos, J., Schraiber, J. G., Wolf, A. B., Gittelman, R. M., et al. (2016). Excavating neanderthal and denisovan DNA from the genomes of Melanesian individuals. Science 352, 235-239. doi: 10.1126/science.aad9416

Wallace, A. R. (1870). Contributions to the Theory of Natural Selection. Basingstoke: Macmillan and Co.

Waller, S. (1993a). Sound and rock art. Nature 363:501. doi: 10.1038/363501a0

Waller, S. (1993b). Sound reflection as an explanation for the context and content of rock art. Rock Art Res. 10, 91-101.
Waller, S. (2002). Psychoacoustic influences of the echoing environments of prehistoric art. Paper Presented at the First Pan-American/Iberian Meeting on Acoustics, Cancun. doi: 10.1121/1.4779166

Waller, S. (2006). "Intentionality of rock art placement deduced from acoustical measurements and echo myths," in Archaeoacoustics, eds C. Scarre, and G. Lawson (Cambridge: Cambridge University Press), 31-39.

Watts, I. (2009). "Red ochre, body painting, and language: interpreting the Blombos ochre," in The Cradle of Language, eds R. Botha and C. Knight (Oxford: Oxford University Press), 62-92.

Whiten, A. (2005). The second inheritance system of chimpanzees and humans. Nature 437, 52-55. doi: 10.1038/nature04023

Whitley, D. (1992). Shamanism and rock art in far western North America huntergatherers. Camb. Archeol. J. 2, 89-113. doi: 10.1017/S0959774300000494

Whitley, D. (1994). "Shamanism, natural modeling and the rock art of far western North America hunter-gatherers," in Shamanism and Rock Art in North America, ed. S. Turpin (San Antonio, TX: Rock Art Foundation), 1-44.

Whitley, D. (1998). Cognitive neuroscience, shamanism, and the rock art of native California. Anthropol. Conscious. 9, 22-37. doi: 10.1525/ac.1998.9.1.22

Winkelman, M. (2002). Shamanism and cognitive evolution. Camb. Archeol. J. 12, 71-101. doi: 10.1017/S0959774302000045

Zuberbühler, K., Cheney, D. L., and Seyfarth, R. M. (1999). Conceptual semantics in a nonhuman primate. J. Comp. Psychol. 113, 33-42. doi: 10.1037/0735-7036. 113.1 .33

Conflict of Interest Statement: The authors declare that the research was conducted in the absence of any commercial or financial relationships that could be construed as a potential conflict of interest.

Copyright (c) 2018 Miyagawa, Lesure and Nóbrega. This is an open-access article distributed under the terms of the Creative Commons Attribution License (CC BY). The use, distribution or reproduction in other forums is permitted, provided the original author(s) and the copyright owner are credited and that the original publication in this journal is cited, in accordance with accepted academic practice. No use, distribution or reproduction is permitted which does not comply with these terms. 